\title{
Macrochelid Mites (Acari: Gamasina: Macrochelidae) Associated with Dung Beetles in Sulawesi, Indonesia
}

\author{
Sri HARTINI ${ }^{1}$, Dhian DWIBADRA ${ }^{1}$ and Gen TAKAKU ${ }^{2 *}$ \\ ${ }^{1}$ Zoology Division (Museum Zoologicum Bogoriense), Research Center for Biology-LIPI, Jl. Raya \\ Jakarta Bogor Km. 46, Cibinong 16911, Indonesia \\ ${ }^{2}$ Biological Laboratory, Hokkaido University of Education Sapporo, 5-3-1 Ainosato, Kita-ku, Sapporo \\ 002-8502, Japan
}

(Received 1 May 2007; Accepted 12 June 2007)

\begin{abstract}
Seventeen species of macrochelid mites belonging to the genera Glyptholaspis and Macrocheles are recorded from Sulawesi, Indonesia. They were all collected from dung beetles (Aphodiinae, Scarabaeinae). Except for Macrocheles kraepelini, all the species are recorded from Sulawesi for the first time. Six species, i.e., M. convexus sp. nov., $M$. donggalensis sp. nov., M. persimilis sp. nov., $M$. pilosellus sp. nov., M. simulans sp. nov., M. variodecoratus sp. nov., are new to science. A key to 55 species of macrochelid mites recorded from Indonesia is also provided.
\end{abstract}

Key words: Acari, Macrochelidae, dung beetles, Sulawesi, Indonesia

\section{INTRODUCTION}

About 50 species of mites of the family Macrochelidae have been recorded from Indonesia by our serial studies (Hartini and Takaku, 2003a-c, 2004, 2006a, b; Hartini et al., 2003, 2005; Takaku, 2001; Takaku and Hartini, 2001) and by previous studies (Berlese, 1905, 1910, 1920; Krantz, 1965, 1967a, b; Oudemans, 1903; Vitzthum, 1931). Previous surveys have been undertaken by us in Sumatra, Kalimantan, Java, Bali, Lesser Sunda Islands, and Papua. Although Sulawesi is known well as the northern part of Wallacea, i.e., the transitional zone between the Oriental and Australian regions, the macrochelid mite fauna is poorly known, represented by only Macrocheles kraepelini (Berlese, 1905) recorded from Bantaeng, South Sulawesi (Halliday, 2000). As a part of our serial studies on the taxonomy and biogeography of Indonesian macrochelids associated with scarabaeid dung beetles, the present paper deals with 17 species, including 6 new species collected in Sulawesi, Indonesia. Besides, a key to 55 species of macrochelid mites recorded from Indonesia is also provided.

\section{MATERIALS AND METHODS}

All the mite specimens were collected from the body surface of scarabaeid dung beetles

\footnotetext{
* Corresponding author: e-mail: takakug@sap.hokkyodai.ac.jp
} 
and were fixed in $70 \%$ ethanol. Where possible, several mite specimens of each presumed species were dissected under a stereoscopic microscope after clearing in lactic acid. Each body part was mounted on a glass slide in Hoyer's medium or PVA medium. Other specimens were mounted whole on slides in Hoyer's medium or PVA medium. Observations were made with a differential interference contrast microscope. Illustrations were prepared with the aid of a drawing tube. All measurements are given in micrometers $(\mu \mathrm{m})$. Measurements in each description are provided as averages and range in parentheses, if more than two specimens were measured. The dorsal chaetotaxy follows Halliday (1987). Other terminology, particularly that for the sternal ornamentation, follows Walter and Krantz (1986) (see Fig. 1 in Hartini and Takaku, 2006a). Synonymies of each species are given in our serial studies, as appropriate (Hartini and Takaku, 2003c, 2006a; Hartini et al., 2003, 2005; Takaku, 2001; Takaku and Hartini, 2001). As for the characters shared by most species of Macrocheles, such characters will be mentioned in the first species description, Macrocheles convexus sp. nov., and the characters will be mentioned in the other species description if their characters differ from usual pattern. The holotype specimen of each new species will be deposited in the collection of the Museum Zoologicum Bogoriense, Bogor, Indonesia (MZB), and paratype specimens and other voucher specimens will be deposited in the MZB and the zoological collections of the Graduate School of Science, Hokkaido University, Sapporo, Japan.

\section{DESCRIPTIONS AND LOCALITY RECORDS}

\section{Glyptholaspis fimicola (Sellnick, 1931)}

Diagnosis: Female. Dorsal length more than 1,100 $\mu \mathrm{m}$; dorsal setae $\mathrm{z} 1$ half as long $\mathrm{j} 1$; insertions of setae j6 and z6 present at the same level; J5 as long as Z5; posterior margin of dorsal shield with small teeth between Z5. Sternal shield adjacent to metasternal shield and ornamented with polygonal distinct ornamentation.

Material examined: 1 female, Tukombo Reserve, Lemah Teno, Bontobahari, Bulu Kumba, South Sulawesi, 28 May 2001, A. Saim leg., ex Aphodius sp.

Habitat: Phoretic on coprophagous beetles, cow dung compost, manure, and so on.

Phoretic hosts: Genera Aphodius and Onitis (Scarabaeidae).

Distribution: Indonesia (Bali, Flores, and Sulawesi), England, Iceland, Italy, Greece, Slovakia, China, India, South Africa, Congo, and North America.

\section{Macrocheles baliensis Takaku and Hartini, 2001}

Diagnosis: Female. Seta j1 slightly pectinate distally, J5 bipectinate, and other dorsal setae simple. Sternal shield ornamented with lines and punctations in anterior half of the shield; ventrianal shields pentagonal, ornamented with reticulate and somewhat semi-concentric pattern.

Material examined: 1 female, Lolan, Bolaang Mongondow, North Sulawesi, 1 December 1999, S. Hartini leg., ex Scarabaeidae sp.; 3 females, Tangkoko Batuangus, North Sulawesi, 25 November 1999, G. Takaku and Hartini leg., ex Aphodius sp.; 125 females, 26 November 
1999, other data same as the above; 2 females, ex cow dung, other data same as the above; 3 females, Lemoh, Tanahwangko, North Sulawesi, 29 November 1999, G. Takaku and S. Hartini leg., ex Onthophagus ? sp.; 5 females, Tampusu, Rumbokan, North Sulawesi, G. Takaku and S. Hartini leg., ex Aphodius sp.; 2 females, Kauditan, North Sulawesi, 30 November 1999, G. Takaku and S. Hartini leg., ex Aphodius sp.; 1 female, ex Onthophagus? sp., other data same as the above; 24 females, Tukombo Reserve, Lemah Teno, Bontobahari, Bulukamba, South Sulawesi, 26-29 May 2001, A. Saim leg., ex Aphodius sp., Paragymnopleurus sp.

Habitat: Phoretic on coprophagous beetles.

Phoretic hosts: Genera Aphodius, Oniticellus, Onitis, Onthophagus, Paragymnopleurus (Scarabaeidae), and Pachylister (Histeridae).

Distribution: Indonesia (Bali, Java, Lombok, Bawean, Sumbawa, Flores, Sumba, and Sulawesi).

\section{Macrocheles dispar (Berlese, 1910)}

Diagnosis: Female. Dorsal shield oval, attenuated posteriorly, surface with reticulation and punctation; j1 plumose distally; j4, z2, z4, r2-4, J5, Z5, and S5 pilose distally; j2, j3, and s2 simple in most of specimens but in some case pilose distally; other setae simple. Sternal shield ornamented with lines and punctations; linea angulata (l.ang.), linea media transversa (l.m.t.), linea oblique posteriores (l.o.p.) with distinct punctations; l.o.p. not bifurcated; l.m.t. complete; center of posterior half of the shield with small punctations.

Material examined: 1 female, 640 m alt., Lore Lindu National Park, Donggala, Kulawi, Bulu Bangabara, Central Sulawesi, 10 May 2002, Erniwati leg., ex Onthophagus sp.; 2 females, 820 m alt., Battang, Warateluwanua, Luwu, South Sulawesi, 29 October 2000, S. Hartini leg., ex Onthophagus sp.; 9 females, 345 m alt., Boganinani National Park, Wartabone, East Dumoga, Mauk Molotong, North Sulawesi, 21-23 May 2002, S. Awit and E. Cholik leg., ex Copris sp., Onthophagus sp.; 3 females, $170 \mathrm{~m}$ alt., Boganinani National Park, Wartabone, East Dumoga, Mainakum, North Sulawesi, 25-27 May 2002, S. Awit and E. Cholik leg., ex Onthophagus sp.

Habitat: Phoretic on coprophagous beetles.

Phoretic hosts: Genera Aphodius, Catharsius, Copris, Onthophagus, Paragymnopleurus (Scarabaeidae), and Enoplotrupes (Geotrupidae).

Distribution: Indonesia (Java, Sumatra, Kalimantan, and Sulawesi), Viet Nam, the Philippines, China (Szechuan), and Taiwan.

Macrocheles hallidayi Walter and Krantz, 1986

Diagnosis: Female. Dorsal shield punctate-reticulate with well developed procurved line; dorsal setae $\mathrm{j} 1$ pilose for greater than half of their length; $\mathrm{z} 1$ shorter than $\mathrm{j} 1$ and not reaching insertions of j2; j5, j6, z5, z6, and J2 simple; S5 and Z5 strongly bipectinate; J5 serrate; other dorsal setae sparsely to strongly bipectinate. Sternal shield with strongly punctate margin along l.ang., and with two deeply punctate linea arcuata (l.arc.), well developed l.m.t., l.o.p., area punctatae posteriores (a.p.p.), and area punctiformes (a.p.f.). Genu IV with seven 
pectinate setae.

Material examined: 1 female, Tountimomoro, North Sulawesi, 27 November 1999, G. Takaku and S. Hartini leg., ex Onthophagus sp.; 10 females, Tangkoko Batuangus Reserve, North Sulawesi, 26 November 1999, G. Takaku and S. Hartini leg., ex Aphodius sp., Copris sp.; 3 females, Tukombo Reserve, Lemah Teno, Bontobahari, Bulu Kumba, South Sulawesi, 29 May 2001, A. Saim leg., ex Scarabaeidae sp.

Habitat: Phoretic on coprophagous beetles.

Phoretic hosts: Genera Aphodius, Catharsius, Copris, Heliocopris, Oniticellus, Onitis, Onthophagus, and Paragymnopleurus (Scarabaeidae).

Distribution: Indonesia (Java, Madura, Sumatra, Bali, Kalimantan, Lombok, Sumbawa, Flores, Sumba, and Sulawesi), India, Thailand, Cambodia, and Malaysia (Sarawak).

\section{Macrocheles jabarensis Hartini and Takaku, 2003}

Diagnosis: Female. Dorsal shield oval, attenuated posteriorly; surface ornamented with reticulation and punctations; most of dorsal setae simple, except for $\mathrm{j} 1$ plumose distally, S5 and Z5 pilose in distal half, J5 entirely pilose, and in some case j4 pilose distally. Sternal ornamentation very similar to that of $M$. dispar.

Material examined: 5 females, Lape Api, Hutan Pangkikima, Langara, Wawonii Island, Southeast Sulawesi, 24-28 April 2004, S. Awit and Darmawan leg., ex Scarabaeidae sp.

Habitat: Phoretic on coprophagous beetles.

Phoretic hosts: Genera Catharsius, Onthophagus, and Paragymnopleurus (Scarabaeidae).

Distribution: Indonesia (Java, Lombok, Sumatra, Sumbawa, Kalimantan, and Sulawesi).

\section{Macrocheles kraepelini (Berlese, 1905)}

Diagnosis: Female. Dorsal shield broadly rounded posteriorly; most of dorsal setae enlarged and pilose, except for simple setae j6, z5, z6, and J2; seta z1 occasionally slightly pilose. Sternal shield with distinct ornamentation; l.ang. with many punctations; posterior 1.arc. concave; 1.o.p. bifurcated; a.p.p. with strong punctations.

Material examined: 1 female, $640 \mathrm{~m}$ alt., Lore Lindu National Park, Donggala, Kulawi, Bulu Bangabara, Central Sulawesi, 10 May 2002, Erniwati leg., ex Onthophagus sp.; 8 females, $560 \mathrm{~m}$ alt., Lore Lindu National Park, Donggala, Kulawi, Bulu Momi, Central Sulawesi, 11 May 2002, Erniwati leg., ex Onthophagus sp.

Habitat: Phoretic on coprophagous beetles, breadfruit compost, and decaying forest litter.

Phoretic hosts: Genera Catharsius, Copris, Coptodactyla, Onitis, Onthophagus, Paragymnopleurus (Scarabaeidae), and Pachylister (Histeridae).

Distribution: Indonesia (Java, Madura, Kalimantan, Sumatra, Lombok, Sumbawa, Flores, West Timor, and Sulawesi), Pakistan, India, Thailand, Viet Nam, Malaysia, Singapore, the Philippines, Samoa, Fiji, Caroline Island, and Australia.

\section{Macrocheles limue Samšiňák, 1962}

Diagnosis: Female. Most dorsal setae simple, except for bipectinate $\mathrm{J} 5$ and distally pilose j1. Sternal ornamentation well developed; 1.ang. convergent medially; two 1.arc. straight; 
posterior edge of sternal shield close to metasternal shield; ventrianal shield expanded and with strongly dimpled reticulation.

Material examined: 1 female, Tukombo Reserve, Lemah Teno, Bontobahari, Bulu Kumba, South Sulawesi, 28 May 2001, A. Saim leg., ex Aphodius sp.

Habitat: Phoretic on coprophagous beetles, compost, soil, cow dung, elephant dung, leaf litter, and so on.

Phoretic hosts: Genera Allonitis, Aphodius, Catharsius, Copris, Garreta, Heliocopris, Heteronitis, Liatongus, Oniticellus, Onitis, Onthophagus, Scarabaeus (Scarabaeidae), and Pachylister (Histeridae).

Distribution: Indonesia (Java, Madura, Sumatra, Bali, Lombok, Sumbawa, Sumba, Papua, Flores, West Timor, and Sulawesi), Ethiopia, Chad, Cameroon, Guinea, Zaire, Rwanda, Zambezi, Burundi, Kenya, Uganda, South Africa, Swaziland, India, China, and the Philippines.

\section{Macrocheles merdarius (Berlese, 1889)}

Diagnosis: Female. Dorsal shield ornamented with granular reticulations, bearing 28 pairs of dorsal setae; all dorsal setae simple; linea oblique anteriores (l.o.a.) of the sternal shield connected by lines; punctation very faint. Genu IV with 6 setae.

Material examined: 1 female, Kauditan, North Sulawesi, 30 November 1999, G. Takaku and S. Hartini leg., ex Aphodius sp.; 1 female, Lolan, Bolaang Mongondow, North Sulawesi, 1 December 1999, S. Hartini leg., ex Scarabaeidae; 4 females, Tukombo Reserve, Lemah Teno, Bontobahari, Bulukumba, South Sulawesi, 26 May 2001, A. Saim leg., ex Aphodius sp.

Habitat: Phoretic on some kinds of beetles, mammals, soil, leaf litter, cow dung, compost, manure, and so on.

Phoretic hosts: Genera Aphodius, Catharsius, Copris, Coptodactyhanaeus, Coptodactyla, Euoniticellus, Lepanus, Liatongus, Notopedana, Onthophagus, Pentodon, Synapsidis (Scarabaeidae), Geotrupes (Geotrupidae), and Pachylister (Histeridae); other beetle families including Lucanidae, Silphidae, Trogidae; also Rodentia.

Distribution: Cosmopolitan. In Indonesia, this species is known from Java, Kalimantan, Bali, Lombok, Papua, Flores, Sumbawa, Sumba, and Sulawesi.

\section{Macrocheles oigru Walter and Krantz, 1986}

Diagnosis: Female. Dorsal setae simple, elongate, surpassing insertions of setae behind them, except for j1, j4, Z5, and S5 pilose distally; sternal ornamentation developed; 1.o.p. bifurcated and reaching to l.m.t.

Material examined: 1 female, Tampusu, Remboken, Minahasa, North Sulawesi, 29 November 1999, S. Hartini leg., ex Aphodius sp.; 1 female, Tukombo, Lemah Teno, Bontobahari, Bulu Kumba, South Sulawesi, 28 May 2001, A. Saim leg., ex Aphodius sp.

Habitat: Phoretic on coprophagous beetles.

Phoretic hosts: Genera Aphodius, Catharsius, Copris, Gymnopleurus, Oniticellus, Onitis, Onthophagus (Scarabaeidae), and Pachylister (Histeridae). 
Distribution: Indonesia (Java, Madura, Sumatra, Bali, Lombok, Sumbawa, Sumba, Flores, and Sulawesi) and India.

\section{Macrocheles sukaramiensis Takaku, 2001}

Diagnosis: Female. Dorsal shield attenuated posteriorly, most of dorsal setae sparsely pilose distally, except for simple setae j5, j6, z5, z6, J2, Z1, and Z3. L.ang. of sternal shield punctate along the lines; l.m.t. distinct and slightly concave; symmetric weak reticulate pattern present between l.ang. and 1.m.t.; outer lines of the reticulation punctate; l.o.p. punctate along lines, and disjunct from 1.m.t.; a pair of short punctate lines present behind 1.o.p.

Material examined: 1 female, Lampe Api, Hutan Pangkikima, Langara, Wawonii Island, Southeast Sulawesi, 24-28 April 2004, S. Awit and Darmawan leg., ex Scarabaeidae sp.

Habitat: Phoretic on coprophagous beetles.

Phoretic hosts: Genera Catharsius, Copris, Onthophagus, and Paragymnopleurus (Scarabaeidae).

Distribution: Indonesia (Java, Sumatra, Kalimantan, and Sulawesi).

Macrocheles sp. aff. glaber (Müller, 1860)

Material examined: 1 female, $345 \mathrm{~m}$ alt., Boganinani National Park, Wartabone, East Dumoga, Mauk Molotong, North Sulawesi, 21-23 May 2002, S. Awit and E. Cholik leg., ex Onthophagus sp.

Habitat: Phoretic on coprophagous beetles.

Phoretic hosts: Genera Aphodius, Catharsius, Copris, Oniticellus, Onitis, Onthophagus (Scarabaeidae), and Pachylister (Histeridae).

Distribution: Indonesia (Java, Madura, Sumatra, Kalimantan, Lombok; Sumbawa, Bawean, Flores, Sumba, West Timor, Papua, and Sulawesi).

\section{Macrocheles convexus sp. nov.}

(Fig. 1)

Type series: Holotype: female (MZB.Acar.2844-1), Lore Lindu National Park, Saluku, Central Sulawesi, 19 October 2002, M. Rofik leg., ex Copris sp. Paratypes: 2 females, $820 \mathrm{~m}$ alt., Battang, Waratelu Wanua, Luwu, South Sulawesi, 29 October 2000, S. Hartini leg., ex Scarabaeidae sp.; 56 females, Lampe Api, Hutan Lalatambaga, Langara, Wawonii Island, Southeast Sulawesi, 29 April 2004, S. Awit and Darmawan leg., ex Scarabaeidae sp.

Female: Length of dorsal shield 1070 (1040-1100), width at level of coxae III 700 (680730) $(n=3)$. Specimens reddish brown.

Dorsum (Fig. 1A): Dorsal shield oval; surface ornamented with faint reticulate pattern or faint lines in anterior region, and without punctation; lateral margin smooth; shield with 28 pairs of dorsal setae and 22 pairs of pores; setae j5, j6, z1, z5, z6, and J2 simple; J5 bipectinate in distal halves or distal 2/3; Z5 and S5 pilose in distal halves; other dorsal setae pilose distally. 



Fig. 1. Macrocheles convexus sp. nov., female, holotype (MZB.Acar.2844-1). A, dorsal shield; B, venter; C, ventral view of gnathosoma; D, epistome (paratype, MZB.Acar.2845-2); E, chelicera (paratype, MZB.Acar.2845-1).

Venter (Fig. 1B): Sternal shield longer than wide; length 181 (173-188), width at level of coxae II 158 (150-165) $(\mathrm{n}=3)$; shield ornamented with lines and without any punctations; 1.ang. and l.o.a. present; one l.arc. present or interrupted medially or absent; 1.m.t. apparently convex anteriorly, without ramus; 1.o.p. not bifurcated and disjunct from 1.m.t.; shield with 3 
pairs of simple setae and 2 pairs of pores; all setae not reaching insertions of setae behind them. Metasternal shields small, oval, each with 1 simple seta and an anterior pore. Epigynial shield without ornamentation; shield with a pair of simple setae on posterior corners. Ventrianal shield oval or triangular, longer than wide; length 310 (303-325), width 251 (245-260) $(n=3)$; shield ornamented with reticulate pattern and without punctation; shield with 3 pairs of preanal setae, 1 pair of paranal setae, and 1 postanal seta; all setae simple, but postanal setae simple or pilose distally. Cribrum located posterior to postanal seta. Opisthogaster with simple or distally pilose setae and a pair of oblong metapodal shields. Postcoxal pore free from podal shield. Anterior extremities of peritreme located at level of setae $\mathrm{z} 1$.

Gnathosoma (Fig. 1C): Well developed and sclerotized: deutosternal groove with 5 transverse rows of denticles; 3 pairs of hypostomal setae and 1 pair of palpcoxal setae simple. Epistome (Fig. 1D) with median process and a pair of lateral elements; median process bifurcated distally and with many small spicules. Fixed digit of chelicera (Fig. 1E) with membranous dorsal seta, robust median tooth, small distal tooth, pilus dentilis, and terminal hook; movable digit with bidentate median tooth, small distal tooth, and terminal hook; length of fixed digit 283 (280-290), and of movable digit 112 (110-113) $(n=3)$.

Legs: Most leg segments with simple and pilose setae, except for coxae I-IV, trochanters I-II, tibia I, and tarsi I-II with only simple setae. Leg chaetotaxy typical for the genus; genu IV with 6 setae. Leg length (except ambulacrum, n=3): leg I, 803 (800-810); leg II, 830 (825-835); leg III, 818 (815-825); leg IV, 1057 (1005-1085).

Sacculus foemineus: Not observed.

Male and other stages: Unknown.

Etymology: The specific name refers to the convex linea media transversa of sternal shield.

Remarks: This species can be easily distinguished from congeners by the distinctive pattern of sternal ornamentation.

\section{Macrocheles donggalensis sp. nov.}

(Fig. 2)

Type series: Holotype: female (MZB.Acar.2837.3), Lore Lindu National Park, Donggala, Kulawi Salua, Central Sulawesi, 12 May 2002, Erniwati leg., ex Onthophagus sp. Paratypes: 7 females, data same as for the holotype; 1 female, Hutan Marga Satwa, Kampung Lawele, Losalemo, Buton Island, Southeast Sulawesi, 5-6 June 2003, Darmawan and P. Aswari leg., ex Onthophagus sp.

Female: Length of dorsal shield 677 (660-700), width at level of coxae III 456 (430-480) $(n=9)$. Specimens reddish brown.

Dorsum (Fig. 2A): Dorsal shield oval; surface ornamented with reticulate pattern and punctations; lateral margin smooth; shield with 28 pairs of dorsal setae and 22 pairs of pores; setae $\mathrm{j} 1, \mathrm{j} 4$ pilose distally; j5, j6, z1, z5, z6, and J2 simple; J5 bipectinate entirely; Z5 and S5 pilose in distal 2/3; other dorsal setae simple or pilose distally.

Venter (Fig. 2B): Sternal shield wider than long; length 137 (128-143), width at level of 

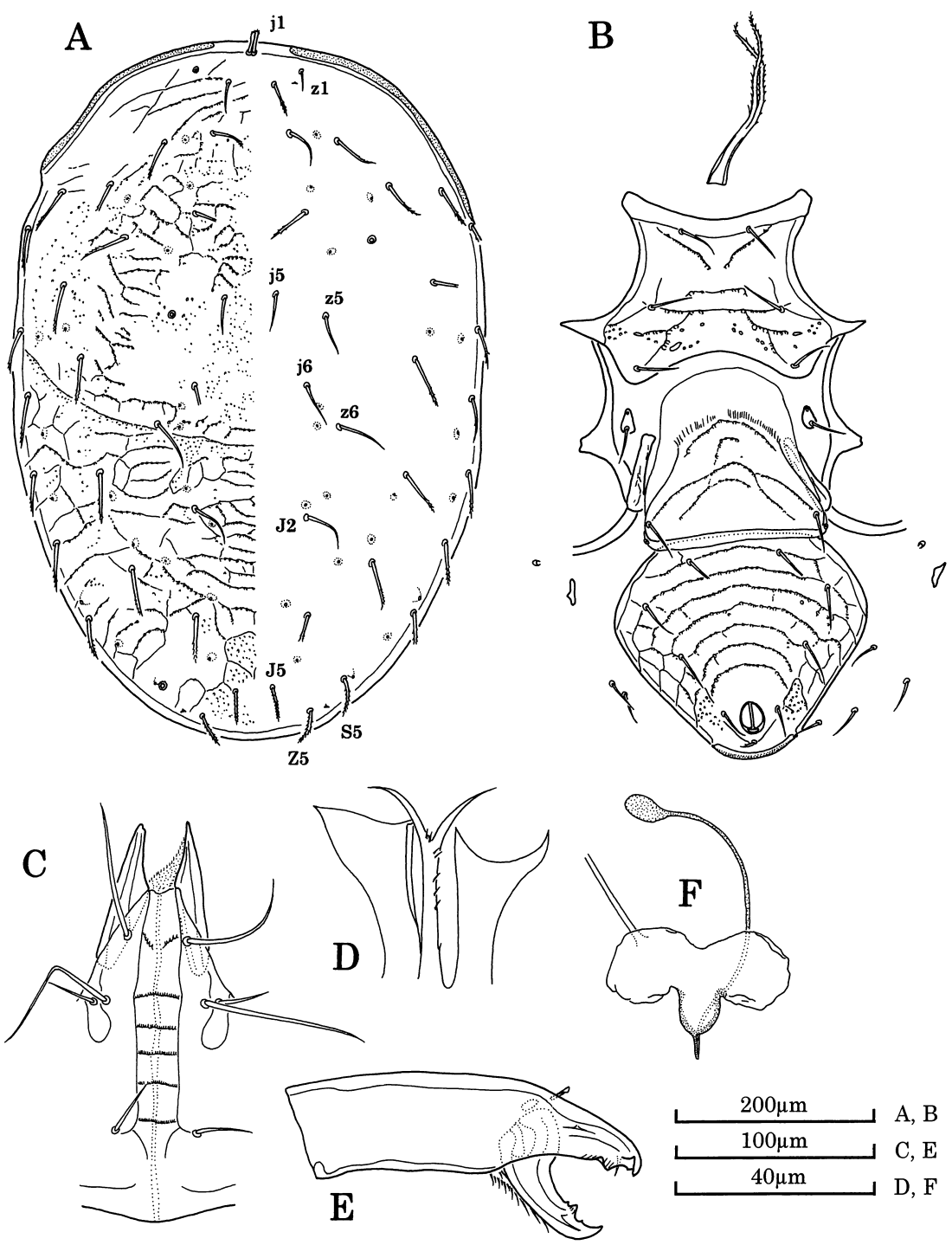

Fig. 2. Macrocheles donggalensis sp. nov., female, holotype (MZB.Acar.2837-3). A, dorsal shield; B, venter; C, ventral view of gnathosoma; D, epistome (paratype, MZB.Acar.2840-1); E, chelicera; F, sacculus foemineus.

coxae II $151(143-155)(n=9)$; shield ornamented with distinct lines and punctations; 1.ang., 1.arc., l.o.a., l.m.t. present in anterior half of shield; each line with punctations; 1.m.t. with ramus; 1.o.p. bifurcated, with distinct punctations, and connected to 1.m.t., but in some specimens, disjunct from 1.m.t. Epigynial shield ornamented with distinct arched lines and punctations; shield with a pair of simple setae on posterior corner. Ventrianal shield pentagonal, wider than long; length 224 (218-235), width 245 (235-253) (n=9); shield ornamented with semiconcentric lines and punctations. 
Gnathosoma (Fig. 2C): Well developed and sclerotized. Epistome (Fig. 2D) and chelicera (Fig. 2E) same as in M. convexus. Length of fixed digit 175 (165-183), and of movable digit $70(63-75)(n=9)$.

Legs: Most leg segments with simple and pilose setae, except for coxae I-IV, trochanters I-IV, tibiae I-II, and tarsus I with only simple setae. Leg length (except ambulacrum, n=9): leg I, 553 (540-575); leg II, 543 (513-570); leg III, 521 (470-555); leg IV, 765 (725-810).

Sacculus foemineus (Fig. 2F): Paired sacculi present; cornu small, rounded distally, and distinct; spermatheca oval.

Male and other stages: Unknown.

Etymology: The specific name is derived from the type locality, Donggala.

Remarks: This species is a typical member of the glaber species group and is similar to Macrocheles oigru Walter and Krantz, 1986 in sternal ornamentation. However, in the present species, dorsal $\mathrm{Z}$ and $\mathrm{S}$ series setae are pilose distally, while those setae are simple except for distally pilose Z5 and S5 in M. oigru.

\section{Macrocheles persimilis sp. nov.}

(Fig. 3)

Type series: Holotype: female (MZB.Acar.2883-13), $1140 \mathrm{~m}$ alt., Lore Lindu National Park, Poso, Lore utara, Malewuko, Central Sulawesi, 17 May 2002, Erniwati leg., ex Onthophagus sp. Paratypes: 2 females, data same as for the holotype; 1 female, $345 \mathrm{~m}$ alt., Boganinani National Park, Wartabone, Dumoga Timur, Mauk Molotong, North Sulawesi, 21-23 May 2002, S. Awit and E. Cholik leg., ex Onthophagus sp.

Female: Length of dorsal shield 865 (820-920), width at level of coxae III 544 (520-580) $(\mathrm{n}=4)$. Specimens reddish brown.

Dorsum (Fig. 3A): Dorsal shield oval, attenuated posteriorly; surface ornamented with distinct reticulate pattern and punctations; lateral margin smooth; shield with 28 pairs of dorsal setae and 22 pairs of pores; setae j1-4 pilose distally; j5, j6, z1, z5, z6, and $\mathrm{J} 2$ simple; $\mathrm{J} 5$ bipectinate entirely; other dorsal setae pilose in distal halves to distal $2 / 3$.

Venter (Fig. 3B): Length of sternal shield almost same as width; length 169 (163-180), width at level of coxae II $176(173-183)(n=4)$; shield ornamented with lines and punctations; 1.ang., one or two l.arc., l.o.a., 1.m.t. present and with punctations; anterior 1.arc. faint; 1.o.p. distinct, with punctations, not bifurcated, and disjunct from 1.m.t. Epigynial shield ornamented with arched lines and punctations; shield with a pair of simple setae on posterior corners. Ventrianal shield pentagonal, longer than wide; length 266 (255-290), width $233(218-255)(n=4)$; shield ornamented with semiconcentric lines and punctations.

Gnathosoma (Fig. 3C): Well developed and sclerotized. Epistome (Fig. 3D) and chelicera (Fig. 3E) same as in M. convexus. Length of fixed digit 228 (225-233), and of movable digit $92(90-95)(n=4)$.

Legs: Most leg segments with simple and pilose setae, except for coxae I-IV, trochanters I-III, tibia I, and tarsus I with only simple setae. Leg length (except ambulacrum, $n=4)$ : leg I, 716 (695-730); leg II, 663 (640-710); leg III, 630 (595-680); leg IV, 998 (945-1085).

Sacculus foemineus: Not observed. 


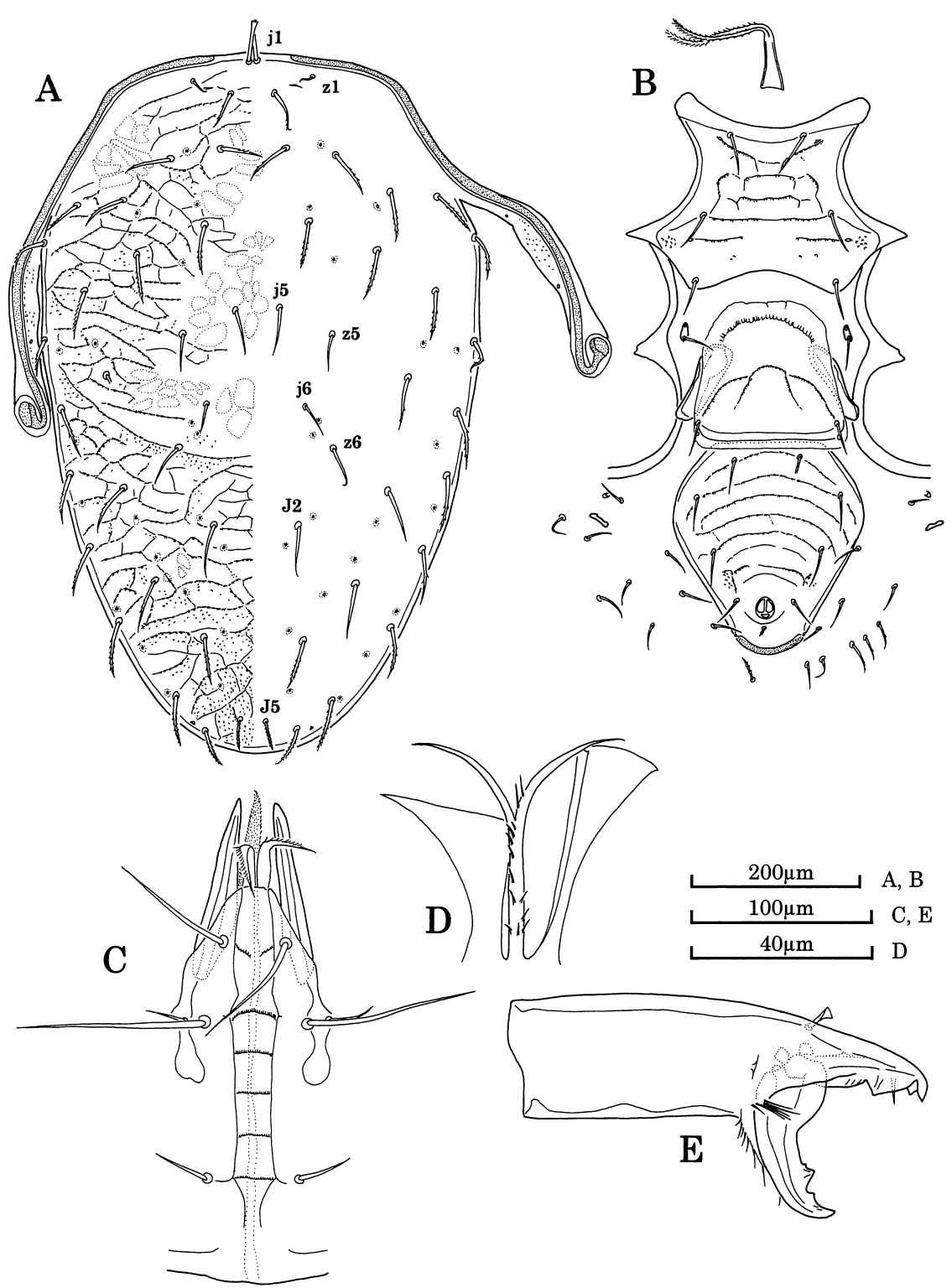

Fig. 3. Macrocheles persimilis sp. nov., female, holotype (MZB.Acar.2883-13). A, dorsal shield; $\mathrm{B}$, venter; $\mathrm{C}$, ventral view of gnathosoma; $\mathrm{D}$, epistome; E, chelicera.

Male and other stages: Unknown.

Etymology: The specific name refers to the remarkable similarity to Macrocheles entetiensis Hartini and Takaku, 2005, recorded from Lesser Sunda Islands, Indonesia.

Remarks: The present species is very similar to Macrocheles entetiensis in the shape of dorsal setae and sternal ornamentation. However, the sternal shield has one or two 1.arc. with distinct punctations in the present species, while only one faint 1.arc. without puncta- 

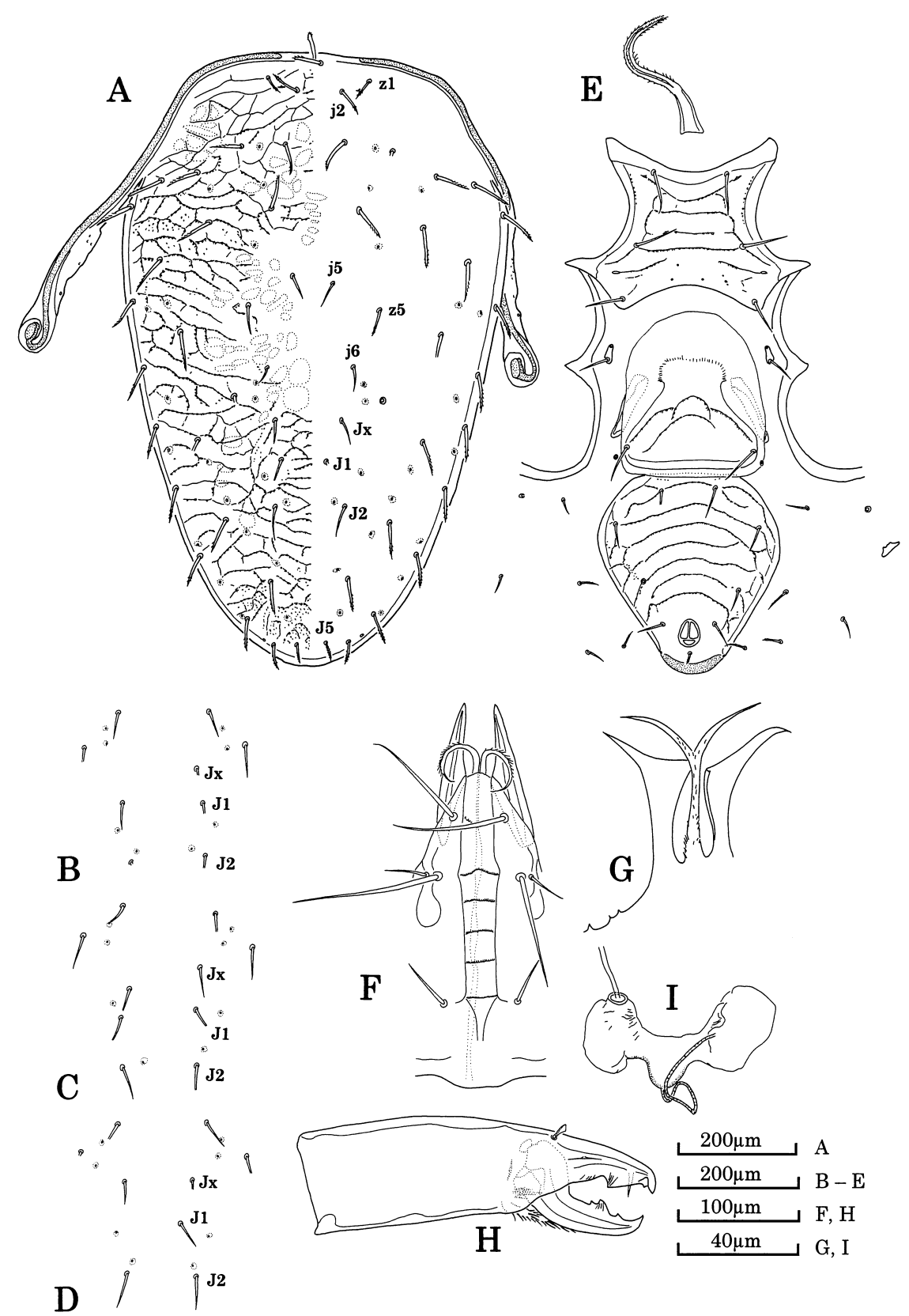

Fig. 4. Macrocheles pilosellus sp. nov., female, holotype (MZB.Acar.2883-10). A, dorsal shield; B-D, variation of dorsal setae (paratypes: B, MZB.Acar.2883-1; C, MZB.Acar.2883-6; D, MZB.Acar.2883-11); E, venter; F, ventral view of gnathosoma; G, epistome (paratype, MZB.Acar.2883-1); H, chelicera; I, sacculus foemineus (paratype, MZB.Acar.2883-1). 
tions is visible in M. entetiensis. Also, the dorsal shield of the present species is larger than that of M. entetiensis.

\section{Macrocheles pilosellus sp. nov.}

(Fig. 4)

Type series: Holotype: female (MZB.Acar.2883-10), 1140 m alt., Lore Lindu National Park, Poso, Lore Utara, Malewuko, Central Sulawesi, 17 May 2002, Erniwati leg., ex Onthophagus sp. Paratypes: 9 females, data same as for the holotype; 1 female, Hutan Marga Satwa, Kampung Lawele, Losalemo, Buton Island, Southeast Sulawesi, 5-6 June 2003, Darmawan and P. Aswari leg., ex Onthophagus sp.; 16 females, Lampe Api, Hutan Pangkikima, Langara, Wawonii Island, Southeast Sulawesi, 24-28 April 2004., S. Awit and Darmawan leg., ex Scarabaeidae sp.

Female: Length of dorsal shield 1013 (940-1045), width at level of coxae III 637 (595665) $(n=11)$. Specimens reddish brown.

Dorsum (Fig. 4A-D): Dorsal shield oval, attenuated posteriorly; surface ornamented with distinct reticulate pattern and punctations; lateral margin smooth; shield with 29 pairs of dorsal setae, and additional unpaired or paired setae Jx (Fig. 4B, C), and 22 pairs of pores; J1 present, rarely unpaired (Fig. 4D); setae j6, z6, J1, and J2 simple; additional setae between j6 and $\mathrm{J} 1$ simple; $\mathrm{j} 5, \mathrm{z} 1$, and $\mathrm{z} 5$ simple or pilose distally; $\mathrm{z} 1$ long and sometime reaching to insertions of $\mathrm{j} 2$; J5 bipectinate in distal halves to $2 / 3$; other dorsal setae pilose distally or pilose in distal halves.

Venter (Fig. 4E): Sternal shield wider than long; length 183 (155-198), width at level of coxae II 194 (188-200) $(\mathrm{n}=11)$; shield ornamented with distinct lines and punctations; 1.ang., two 1.arc., 1.o.a., 1.m.t. present and usually with punctations; 1.o.a. connected to anterior 1.arc.; l.o.p. distinct, with punctations, not bifurcated, and disjunct from 1.m.t., but in some specimens, connected to l.m.t. Epigynial shield ornamented with arched lines and punctations; shield with a pair of simple setae on posterior corner. Ventrianal shield oval or pentagonal, longer than wide; length 332 (315-350), width 297 (258-320) ( $n=11)$; shield ornamented with semiconcentric lines and punctations; preanal setae Jv3 rarely pilose distally.

Gnathosoma (Fig. 4F): Well developed and sclerotized. Epistome (Fig. 4G) and chelicera (Fig. 4H) same as in M. convexus. Length of fixed digit 279 (260-293), and of movable digit $113(108-115)(\mathrm{n}=9)$.

Legs: Most leg segments with simple and pilose setae, except for coxae I-III, trochanters I-II, and tarsus I with only simple setae. Leg length (except ambulacrum, n=11): leg I, 892 (800-960); leg II, 828 (765-890); leg III, 814 (765-860); leg IV, 1182 (1090-1245).

Sacculus foemineus (Fig. 4I): Paired sacculi present; cornu small, rounded distally, and distinct; spermathecal duct broken.

Male and other stages: Unknown.

Etymology: The specific name refers to number and type of dorsal setae in the present species, which has 29 pairs of setae and 1 or 2 additional setae rather than the 28 pairs found in most species of Macrocheles. 


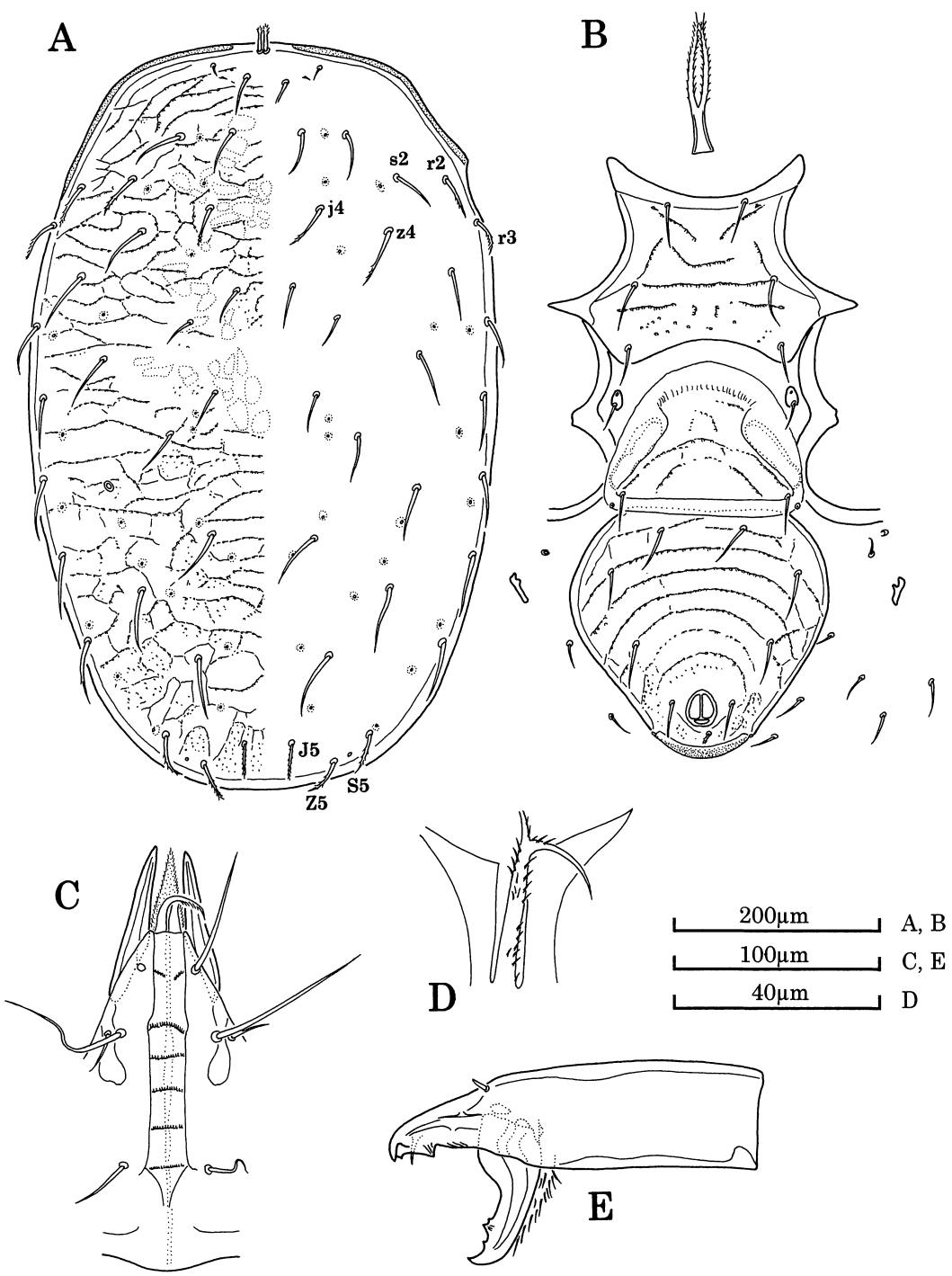

Fig. 5. Macrocheles simulans sp. nov., female, holotype (MZB.Acar.2841-4). A, dorsal shield; B, venter; C, ventral view of gnathosoma; D, epistome; E, chelicera.

Remarks: This species is closely related to Macrocheles persimilis also collected from Sulawesi, Indonesia. These two species share the following characters: most of the dorsal setae are pilose distally; on the sternal shield, two punctate 1.arc. are present, 1.o.p. is not bifurcated, and disjunct from 1.m.t. However, M. pilosellus has dorsal setae J1 and additional setae present, while there are 28 pairs in M. persimilis. Besides, the two species differ in body size; the average dorsal length exceeds $1 \mathrm{~mm}$ in the present species, while it is less than $900 \mu \mathrm{m}$ in M. persimilis. 
Macrocheles simulans sp. nov.

(Fig. 5)

Type specimen: Holotype: female (MZB.Acar.2841.4), $560 \mathrm{~m}$ alt., Lore Lindu National Park, Donggala, Kulawi, Bulu Momi, Central Sulawesi, 11 May 2002, Erniwati leg., ex Onthophagus sp.

Female: Length of dorsal shield 695, width at level of coxae III $450(n=1)$. Specimen reddish brown.

Dorsum (Fig. 5A): Dorsal shield oval; surface ornamented with distinct reticulate pattern and punctations; lateral margin smooth; shield with 28 pairs of dorsal setae and 22 pairs of pores; setae j4, z4, s2, r2, and r3 pilose distally; S4 slightly pilose; J5 bipectinate entirely; Z5 and S5 pilose in distal halves; other dorsal setae simple.

Venter (Fig. 5B): Sternal shield wider than long; length 135, width at level of coxae II $150(\mathrm{n}=1)$; shield ornamented with distinct lines and punctations; l.ang., one 1.arc., 1.o.a., 1.m.t. distinct and with punctations; 1.o.p. distinct with punctations, not bifurcated, and disjunct from l.m.t. Epigynial shield ornamented with distinct arched lines and punctations; shield with a pair of simple setae on posterior corner. Ventrianal shield pentagonal, wider than long; length 235 , width $250(\mathrm{n}=1)$; shield ornamented with distinct semi-concentric lines and punctations.

Gnathosoma (Fig. 5C): Well developed and sclerotized. Epistome (Fig. 5D) and chelicera (Fig. 5E) same as in M. convexus. Length of fixed digit 183, and of movable digit $75(\mathrm{n}=1)$.

Legs: Most leg segments with simple and pilose setae, except for coxae I-IV, trochanters I-III, tibia I, and tarsi I-II with only simple setae. Leg length (except ambulacrum, n=1): leg I, 530; leg II, 495; leg III, 445; leg IV, 695.

Sacculus foemineus: Not observed.

Male and other stages: Unknown.

Etymology: The specific name refers to the similarity of the present species to Macrocheles dispar, which is distributed widely in Southeast Asia, in the shape of dorsal setae and sternal ornamentation.

Remarks: This species is very similar to M. dispar in the shape of dorsal setae and sternal ornamentation. However, sternal l.arc. of the present species is more distinct than that $M$. dispar, and has punctations. L.o.p. and l.ang. of the present species have punctations, and are also more distinct than those of M. dispar.

\section{Macrocheles variodecoratus sp. nov.}

(Fig. 6)

Type series: Holotype: female (MZB.Acar.2885.1), Lore Lindu National Park, Saluku, Central Sulawesi, 19 October 2002, M. Rofik leg., ex Copris sp. Paratypes: 2 females, data same as for holotype; 9 females, ex Scarabaeidae sp., other data same as for holotype; 12 females, Swakamargasatwa Tukombo, Lemah Teno, Bontobahari, Bulukumba, South Sulawesi, 29 May 2001, A. Saim leg. ex Scarabaeidae sp.; 3 females, 345 m alt., Boganinani National Park, Wartabone, Dumoga Timur, Mauk Molotong, North Sulawesi, 21-23 May 2002, S. Awit and E. Cholik leg., ex Paragymnopleurus sp.; 15 females, Lampe Api, Hutan 


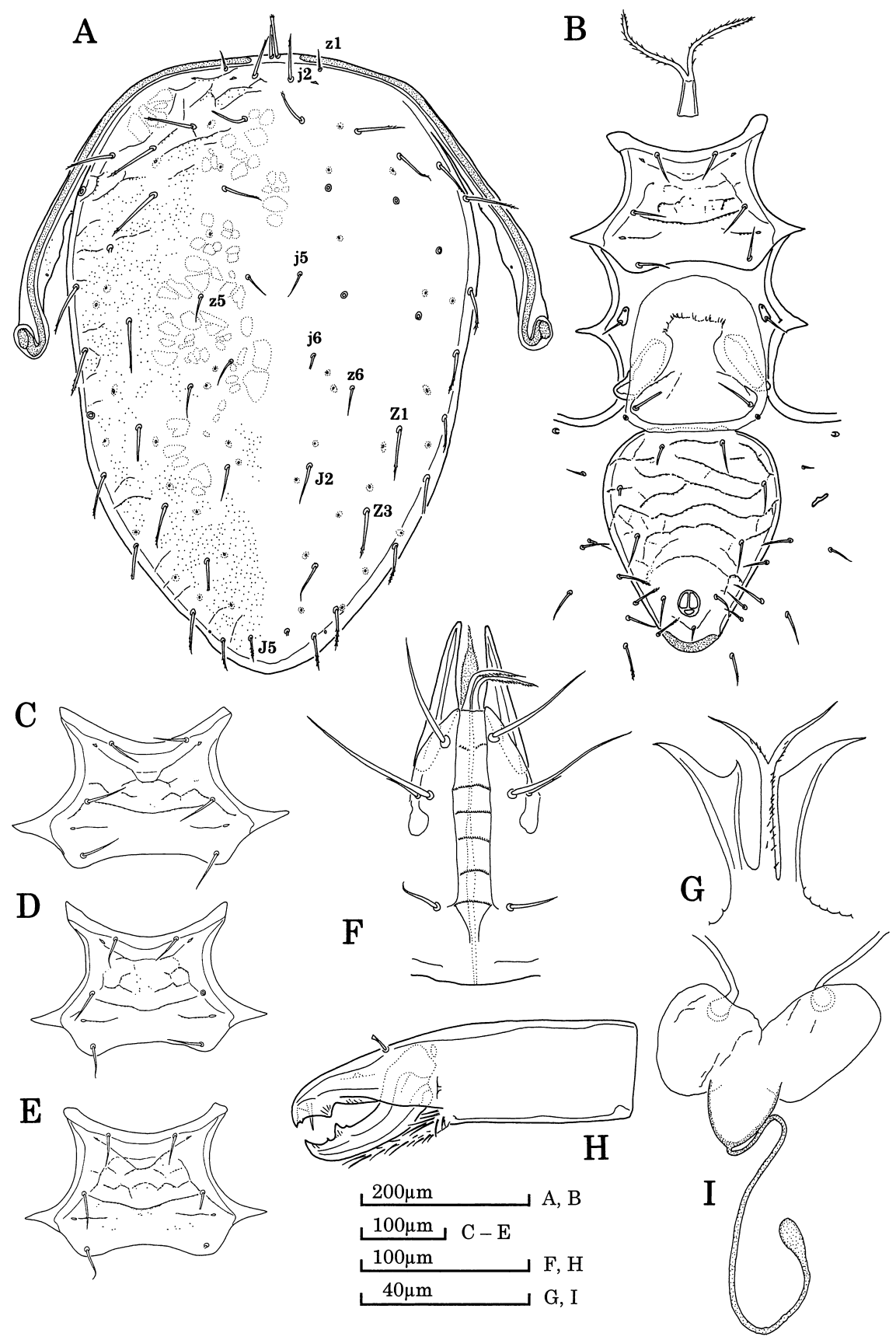

Fig. 6. Macrocheles variodecoratus sp. nov., female, holotype (MZB.Acar.2885-1). A, dorsal shield; B, venter; C-E, variation of sternal ornamentation (paratypes: C, MZB.Acar.2891-1; D, MZB.Acar.2885-3; E, MZB.Acar.2885-2); F, ventral view of gnathosoma; G, epistome (paratype, MZB.Acar.2885-2); H, chelicera (paratype, MZB.Acar.2885-2); I, sacculus foemineus (paratype, MZB.Acar.2849-4). 
Pangkikima, Langara, Wawonii Island, Southeast Sulawesi, 24-28 April 2004, S. Awit and Darmawan leg., ex Scarabaeidae sp.

Female: Length of dorsal shield 754 (690-810), width at level of coxae III 497 (440-550) $(\mathrm{n}=24)$. Specimens yellowish brown.

Dorsum (Fig. 6A): Dorsal shield oval, attenuated posteriorly; faint lines or reticulation with punctations present in anterior region; surface with minute punctations laterally or in whole; lateral margin smooth; shield with 28 pairs of dorsal setae and 22 pairs of pores; setae $\mathrm{j} 5$, j6, z1, z5, z6, and J2 simple; J5 bipectinate in distal halves to 2/3; j2, Z1, and Z3 pilose distally, but simple in some cases; other dorsal setae slightly pilose distally.

Venter (Fig. 6B-E): Sternal shield wider than long; length 126 (115-138), width at level of coxae II $152(140-165)(n=26)$; ornamentation of sternal shield different in each population as follows:

1) In northern population, 1.ang. and 1.arc. faint; 1.arc. and 1.o.a. with minute punctations; l.m.t. with punctations and slightly convex posteriorly; 1.o.p. faint and without punctation (Fig. 6C).

2) In central population, l.ang. and 1.arc. faint; minute punctation located sparsely in anterior half of shield; 1.m.t. with punctations and convex posteriorly; 1.o.p. with punctations (Fig. 6B, D).

3) In southern population, l.ang. faint or absent; 1.o.a. and l.arc. with minute punctations; 1.m.t. convex posteriorly, with medial ridge and punctations; 1.o.p. with punctations (Fig. 6E).

L.o.p. not bifurcated and disjunct from 1.m.t. Epigynial shield ornamented with faint arched lines and punctations; shield with a pair of simple setae on posterior corner. Ventrianal shield oval or triangular, longer than wide; length 268 (220-303), width 219 $(165-258)(n=26)$; shield ornamented with semiconcentric lines and punctations.

Gnathosoma (Fig. 6F): Well developed and sclerotized. Epistome (Fig. 6G) and chelicera (Fig. 6H) same as in M. convexus. Length of fixed digit 208 (188-225), and of movable digit $90(78-100)(\mathrm{n}=23)$.

Legs: Most leg segments with simple and pilose setae, except for coxae I-IV, trochanters

Table 1. Geographic variation in some morphological traits of Macrocheles variodecoratus sp. nov. collected from three different parts of Sulawesi. Measurements are provided as averages and range in parentheses.

\begin{tabular}{lccc}
\hline \multirow{2}{*}{ Characters } & \multicolumn{3}{c}{ Localities } \\
\cline { 2 - 4 } & North $(\mathrm{n}=4)$ & Central $(\mathrm{n}=11)$ & South $(\mathrm{n}=12)$ \\
\hline Dorsal length $(\mu \mathrm{m})$ & $773(710-810)$ & $761(720-810)^{\dagger}$ & $743(690-800)^{\dagger}$ \\
Dorsal width $(\mu \mathrm{m})$ & $528(485-550)$ & $499(470-530)^{\dagger}$ & $486(440-520)^{\dagger}$ \\
Sternal length $(\mu \mathrm{m})$ & $127(118-135)$ & $129(120-138)$ & $123(115-128)$ \\
Sternal width $(\mu \mathrm{m})$ & $162(158-165)$ & $151(143-160)$ & $152(140-160)$ \\
Ventrianal length $(\mu \mathrm{m})$ & $284(263-303)$ & $277(245-295)$ & $257(220-278)$ \\
Ventrianal width $(\mu \mathrm{m})$ & $237(205-258)$ & $229(210-245)$ & $205(165-233)$ \\
Ridge in l.m.t. & undeveloped & undeveloped & developed \\
Punctation in l.o.p. & absent & present & present \\
\hline
\end{tabular}

$\dagger: n=10 ;: n=11$ 
I-III, tibiae I, and tarsi I-II with only simple setae. Leg length (except ambulacrum; $\mathrm{n}=25$ for leg I, III, IV, and n=24 for leg II): leg I, 587 (515-650); leg II, 557 (485-635); leg III, 529 (455-610); leg IV, 737 (655-840).

Sacculus foemineus (Fig. 6I): Paired sacculi present, broadly joined medially; cornu small, rounded distally, and distinct; spermatheca oval.

Male and other stages: Unknown.

Etymology: The specific name refers to variable ornamentation of the dorsal and sternal shields.

Remarks: The present species is similar to Macrocheles dispar (Berlese, 1910) in sternal ornamentation. However, it differs from the latter in the following characteristics (corresponding conditions of $M$. dispar in parentheses): 1) dorsal ornamentation faint and reticulate pattern restricted to anterior region (shield ornamented with reticulate pattern and punctations in most parts); 2) dorsal setae s4-6, Z1, Z3, S1, S2, and S4 pilose distally (simple); 3) l.m.t. convex posteriorly and with ridge medially in some cases (not convex and without medial ridge). The present species shows geographic variation in its dorsal and sternal ornamentation, as shown in Table 1. In addition to differences in ornamentation, measurements of several parts of the body tend to decrease from north to south.

Key to genera of the family Macrochelidae occurring in Indonesia (female)

(Genus Geholaspis is omitted from this key because of insufficient original description.)

1. Epistome unipartite; trochanter III with 4 setae. Neopodocinum

.. Epistome tripartite; trochanter III with 5 setae.

2. Sternal shield with polygonal crenulate ridges; posterior margin reaching laterally to the level of posterior corners of coxae III, fused with endopodal sclerites, and posterior corners adjacent to metasternal shields (except for Glyptholaspis gressitti).

Glyptholaspis

_. Sternal shield with variously ornamented; posterior margin distant from metasternal shields.

3. Femur II with sclerotized spurs; dorsal vertical setae (j1) inserted on an anterior projection of the dorsal shield (except for Holostaspella fatimahae and H. rosichoni).

Holostaspella

_. Femur II without sclerotized spurs; dorsal shield without anterior projection.

Macrocheles

Key to species of the genus Neopodocinum in Indonesia (female)

(Neopodocinum vosi recorded from Sumatra is omitted from this key because female of the species has not been recorded until now.)

1. Anal shield expanded and triangular. 2

. Anal shield rounded.

2. Anal shield with 2 pairs of preanal setae.

N. halimunense Hartini and Takaku, 2003

Anal shield without preanal setae.

N. maius Berlese, 1911

3. Dorsal shield bearing more than 40 pairs of dorsal setae; tarsus I with ambulacrum 
and remnant of claw.

_. Dorsal shield with 28-31 pairs of dorsal setae; tarsus I without ambulacrum and claw.

4. Dorsal setae j5 to J5 simple. N. kalimantanense Hartini and Takaku, 2004

. Dorsal setae j5 to J5 pectinate. N. bosschai (Oudemans, 1901)

5. Unpaired dorsal seta Jx absent.

.. Unpaired dorsal seta Jx present.

6. Dorsal shield with 30 pairs of minute dorsal setae; hypostomal setae simple.

N. sinicum $\mathrm{Li}$ and $\mathrm{Gu}, 1987$

. Dorsal shield with 31 pairs of dorsal setae most dorsal setae, long pectinate; internal posterior hypostomal setae thick and conical.

N. spinirostris (Berlese, 1910)

7. Deutosternal groove with 4 transverse rows of denticles. .... N. javense Krantz, 1965

. Deutosternal groove with 5 transverse rows of denticles.

8. Dorsal setae j3, z2, z4, s5, Z1, Z3, and Z4 simple; opisthogaster with simple or slightly pilose setae.

N. subjaspersi Hartini and Takaku, 2003

_. Dorsal setae j3, z2, z4, s5, Z1, Z3, and Z4 pectinate; opisthogastric setae plumose and broadened medially.

N. jaspersi (Oudemans, 1900)

\section{Key to species of the genus Holostaspella in Indonesia (female)}

1. Dorsal shield bearing 29 pairs of dorsal setae and without anterior projection. .2

. Dorsal shield bearing 28 pairs of dorsal setae and with anterior projection.

2. Dorsal shield sculptured with fossae and with minute punctations; most dorsal setae feather-like.

H. fatimahae Hartini and Takaku, 2006

_. Dorsal shield sculptured laterally and posteriorly, and with strong punctations throughout; most dorsal setae pectinate.

H. rosichoni Hartini and Takaku, 2006

3. Most dorsal setae simple; setae j1 broadly plumose; J5 pectinate.

H. bifoliata (Trägårdh, 1952)

- Most dorsal setae pectinate.

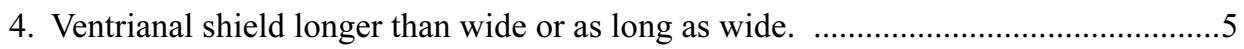

. Ventrianal shield wider than long.

5. Dorsal setae z1 pectinate; ventrianal shield reduced; two pairs of oblong platelets present between epigynial and ventrianal shields.

H. katakurai Hartini and Takaku, 2003

_. Dorsal setae z1 simple; ventrianal shield not reduced; platelets between epigynial and ventrianal shields absent.

H. foai Berlese, 1910

6. Dorsal shield ornamented with sclerotized ridges laterally; all sternal, epigynial, and preanal setae simple.

H. berlesei Krantz, 1967

_. Dorsal shield without sclerotized ridges; some sternal, epigynial, and sometimes preanal setae pectinate.

H. moderata Berlese, 1920

\section{Key to species of the genus Glyptholaspis in Indonesia (female)}

1. Unpaired dorsal seta Jx present; posterior margin of sternal shield distant from metasternal shield.

G. gressitti Krantz, 1967 
_. Jx absent; posterior margin of sternal shield adjacent to metasternal shield.

2. Insertions of setae j6 and z6 present at the same level; dorsal length more than $1,100 \mu \mathrm{m}$. G. fimicola (Sellnick, 1931)

_. Insertions of setae j6 and z6 present not at the same level; dorsal length less than $1,100 \mu \mathrm{m}$.

G. asperrima (Berlese, 1905)

\section{Key to species of the genus Macrocheles in Indonesia (female)}

1. Dorsal shield bearing 27-28 pairs of dorsal setae. 2

. Dorsal shield bearing 29-30 pairs of dorsal setae.

2. Dorsal shield bearing 27 pairs of dorsal setae; z6 absent.

M. erniae Hartini and Takaku, 2006

. Dorsal shield with 28 pairs of setae; z6 present.

3. All dorsal setae simple and short, except for pilose $\mathrm{J} 5$ (and j1 slightly pilose in $M$. baliensis and M. limue).

_. Some dorsal setae pilose or plumose at least distally.

4. Posterior edge of sternal shield close to metasternal shield; 1.ang. convergent medially; ventrianal shield expanded laterally.

M. limue Samšiňák, 1962

_. Posterior edge of sternal shield disjunct from metasternal shield; l.ang. not as above; ventrianal shield subtriangular or pentagonal, not expanded.

5. L.o.a. of sternal shield connected by transverse lines. ............................................6

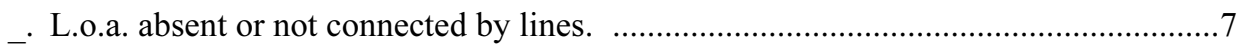

6. Transverse lines of sternal shield with distinct punctations; genu IV with 7 setae.

M. subbadius (Berlese, 1904)

.. Shield with fine lines without punctation; genu IV with 6 setae.

............................................................................ M. merdarius (Berlese, 1889)

7. Anterior half of sternal shield ornamented with somewhat reticulate pattern of punctate lines.

M. baliensis Takaku and Hartini, 2001

_. Ornamentation of sternal shield faint and without reticulate ornamentations.

8. All dorsal setae pilose in most length.

M. krantzi Evans and Hyatt, 1963

.. Some dorsal setae at least j6, z5, z6, and $\mathrm{J} 2$, simple.

9. Dorsal setae j1 extremely short and palmate. ... M. plumosus Evans and Hyatt, 1963

_. Dorsal setae j1 normal length and pilose distally.

M. sukabumiensis Hartini and Takaku, 2003

10. Some dorsal setae pilose or pectinate entirely or in distal $2 / 3$

_. Dorsal setae simple, pilose or pectinate distally or in distal half, except for J5 pilose for the entire length.

11. Dorsal setae j3, j4, z4, s4, and s5 simple. M. crispa (Berlese, 1910)

. Dorsal setae j3, j4, z4, s4, and s5 pilose or bipectinate.

12. L.m.t. of sternal distinctly convex anteriorly (Fig. 1B). M. convexus sp. nov.

- L.m.t. almost straight or convex posteriorly.

13. Genu IV with 7 setae. M. hallidayi Walter and Krantz, 1986

_. Genu IV with 6 setae. 
14. L.o.p. of sternal shield bifurcated and connected to l.m.t. .......................................15

_. L.o.p. not bifurcated and not connected to l.m.t.

15. L.arc. and a.p.p. with coarse punctations.

M. kraepelini (Berlese, 1905)

_. L.arc. and a.p.p. without coarse punctations, with only small punctuations (Fig. 2B).

M. donggalensis sp. nov.

16. Reticulate ornamentation of dorsal shield very faint and restricted in anterior and lateral margin; dorsal punctations minute (Fig. 6A).

M. variodecoratus sp. nov.

_. Reticulations distinct and covering dorsal shield thoroughly except anterocentral area; dorsal punctations distinct and not minute.

17. Sternal shield bearing one or two distinct l.arc. with punctations (Fig. 3B).

M. persimilis sp. nov.

_. Sternal shield with one faint or undulate l.arc.

18. L.m.t. of sternal shield complete and with punctations along line.

M. kalimantanensis Hartini and Takaku, 2004

_. L.m.t. complete and without punctation along line.

M. baramensis Evans and Hyatt, 1963

19. Posterior half of sternal shield ornamented with a band of coarse deep punctations across the full width of the shield.

M. muscaedomesticae (Scopoli, 1772)

. Sternal shield without abovementioned ornamentation.

20. Sternal shield without 1.m.t.; shield ornamented with punctations laterally.

M. sumbaensis Hartini and Takaku, 2005

. Sternal shield with 1.m.t.; shield ornamented with lines and punctations.

21. Sternal shield with only linear ornamentation, without any punctations.

. Sternal shield ornamented with lines and punctations.

22. Dorsal shield ornamented with faint reticulations and punctations; sternal shield wider than long.

M. jonggolensis Hartini and Takaku, 2003

. Dorsal shield ornamented with distinct reticulations and punctations; sternal shield almost as long as wide.

M. manokwariensis Hartini and Takaku, 2006

23. L.o.p. bifurcated, and the posterior end reaching to sternal pores 2 and sternal setae 3; distinct a.p.p. present posterior to l.o.p.

L.o.p. not bifurcated; a.p.p. reduced or absent.

24. At least, dorsal setae j1, j3, z2, z4, s2, s4-6, r2-4, Z1, and Z5 pilose distally or in distal halves.

M. agilis Halliday, 2000

. Setae j1, j4, Z4, and Z5 pilose distally or in distal halves.

.25

25. Most dorsal setae elongate, surpassing insertions of setae behind them.

M. oigru Walter and Krantz, 1986

. Most dorsal setae not elongate, and not surpassing insertions of setae behind them. ..

M. sp. aff. glaber (Müller, 1860)

26. Most of dorsal setae simple.

. Most of dorsal setae pilose distally.

27. Dorsal setae j1, Z4, Z5, S4, and S5 pilose distally; J5 pilose entirely or in distal half; other setae simple.

M. monticola Takaku and Hartini, 2001

_. Dorsal setae j1, j4, Z5, and S5 pilose distally; J5 pilose entirely; other setae simple. 
M. jabarensis Hartini and Takaku, 2003

28. Anterior half of sternal shield ornamented with symmetric weak reticulate pattern. ... M. sukaramiensis Takaku, 2001

. Anterior half of sternal shield with one l.arc.

29. Dorsal setae Z1, Z3, S1, and S2 pilose distally.

M. entetiensis Hartini and Takaku, 2005

Dorsal setae Z1, Z3, S1, and S2 simple.

30. Dorsal setae $z 4, \mathrm{~s} 2, \mathrm{r} 2$, and $\mathrm{r} 3$ simple.

M. nalani Walter and Krantz, 1980

Dorsal setae z4, s2, r2, and r3 pilose distally.

31. Sternal ornamentation reduced, l.arc. faint; ventrianal shield longer than wide.

M. dispar (Berlese, 1910)

_. Sternal ornamentation developed, l.arc. more distinct and with punctations; ventrianal shield wider than long (Fig. 5B).

M. simulans sp. nov.

32. Lateral margin of dorsal shield crenulate; shield bearing 29 pairs of dorsal setae, $\mathrm{j} 1$ broad anteriorly, strongly pectinate in the margin.

M. woroae Hartini and Takaku, 2006

_. Lateral margin of dorsal shield smooth; shield with 29 or 30 pairs of setae, j1 pilose or plumose distally.

33. Most of the dorsal setae simple.

. Most of the dorsal setae pilose distally.

34. Dorsal setae very short; Z5 pilose in distal half; ventrianal shield triangular and long.

M. timikaensis Hartini and Takaku, 2006

. Dorsal setae long; Z5 entirely pilose; ventrianal shield wider than long.

M. kojimai Hartini and Takaku, 2006

35. Dorsal shield with 29 pairs of dorsal setae; posterior half of sternal shield with a straight line connecting sternal pores 2 .

M. borealis Halliday, 2000

_. Dorsal shield with 29 pairs of dorsal setae and additional unpaired or paired setae (Fig. 4A-D); posterior half of sternal shield with a pair of punctate lines (1.o.p.) (Fig. 4E).

M. pilosellus sp. nov.

\section{ACKNOWLEDGEMENTS}

We would like to express our sincere thanks to Drs. Arie Budiman and Siti Nuramaliati Prijono of Lembaga Ilmu Pengetahuan Indonesia (LIPI) (=Indonesian Institute of Sciences) for their encouragement and giving us an opportunity to study this subject and use facilities; and two anonymous reviewers for their critical reading of the manuscript and for their valuable suggestions. Sincere thanks are extended to staff and technicians in the Entomology Laboratory, Zoology Division, Research Center for Biology-LIPI, who collected valuable specimens. This study was partly supported by Grant-in-Aid for Scientific Research (Nos. 11691161, 14740468, 17405011) from Japan Society for the Promotion of Science. 


\section{REFERENCES}

Berlese, A. (1889) Acari, Myriopoda et Scorpiones Hucusque in Italia Reperta, fasc. 52 N. 1, Tipografia del Seminario, Padova.

Berlese, A. (1905) Acari nuovi. Manipulus IV. Redia, 2: 154-176.

Berlese, A. (1910) Lista di nuove specie e nuovi generi di Acari. Redia, 6: 242-271.

Berlese, A. (1920) Centuria quinta di Acari nuovi. Redia, 14: 143-195.

Halliday, R. B. (1987) Further observations on the dorsal idiosomal chaetotaxy in the Macrochelidae (Acarina). International Journal of Acarology, 13: 51-53.

Halliday, R. B. (2000) The Australian species of Macrocheles (Acarina: Macrochelidae). Invertebrate Taxonomy, 14: 273-326.

Hartini, S. and G. Takaku (2003a) Mites of the macrochelid genus Neopodocinum (Arachnida: Acari: Gamasida: Macrochelidae) associated with dung beetles in West Java, Indonesia. Species Diversity, 8: 47-65.

Hartini, S. and G. Takaku (2003b) A new species of Holostaspella (Arachnida: Acari: Macrochelidae) from Kalimantan, Indonesia. Species Diversity, 8: 347-351.

Hartini, S. and G. Takaku (2003c) Javanese species of the mite genus Macrocheles (Arachnida: Acari: Gamasina: Macrochelidae). Zoological Science, 20: 1261-1272.

Hartini, S., G. Takaku and H. Katakura (2003) Macrochelid mites of the genus Macrocheles (Acari: Macrochelidae) in Kalimantan, Indonesia. International Journal of Acarology, 29: 307-313.

Hartini, S. and G. Takaku (2004) Neopodocinum mites (Arachnida: Acari: Macrochelidae) in Kalimantan. Species Diversity, 9: 77-89.

Hartini, S., G. Takaku, J. Kojima and H. Katakura (2005) Macrochelid mite fauna in the eastern part of the Lesser Sunda Islands, with description of two new species. Entomological Science, 8: 201-209.

Hartini, S. and G. Takaku (2006a) Mites of the genus Macrocheles (Acari: Gamasida: Macrochelidae) associated with dung beetles in Papua, Indonesia. Journal of the Acarological Society of Japan, 15: 29-46.

Hartini, S. and G. Takaku (2006b) Two new species of the genus Holostaspella (Acari: Macrochelidae) associated with dung beetles in Papua, Indonesia. International Journal of Acarology, 32: 169-173.

Krantz, G. W. (1965) A review of the genus Neopodocinum Oudemans, 1902 (Acarina, Macrochelidae). Acarologia, 7: 139-226.

Krantz, G. W. (1967a) A review of the genus Holostaspella Berlese, 1904 (Acarina: Macrochelidae). Acarologia, 9 (Supplement): 91-146.

Krantz, G. W. (1967b) Acarina: Mesostigmata: Macrochelidae. Insects of Micronesia, 3: 149-154.

Müller, J. (1860) Insektenepizoën der mährischen Fauna. Jahresheft der Naturwissenschaftlieben Section der k. k. mägr. schles. Gesellschaft für Ackerbau. Nature- und Landeskunde, 1859: 157-184.

Oudemans, A. C. (1903) Acarologische Aanteekeningen. VIII. Entomologische Berichten, 1: 100-103.

Samšiňák, K. (1962) Neue entomophile Acari aus China. Acta Societatis Entomologicae Čechosloveniae, 59: 186204.

Sellnick, M. (1931) Zoologische Forschungsreise nach den Janischen Inseln und dem Peloponnes. Sitzungsberichte der Akademie der Wissenschaften in Wien. Mathematisch Naturwissenschaftlichen Klasse, Abtheilung L. 140: 693-776.

Takaku, G. (2001) Macrochelid mites (Acari: Macrochelidae: Macrocheles, Holostaspella) associated with scarabaeid beetles in Sumatra, Indonesia. Tropics, 10: 497-507.

Takaku, G. and S. Hartini (2001) Macrochelid mites (Arachnida: Acari: Macrochelidae: Glyptholaspis, Macrocheles, Neopodocinum) associated with dung beetles in Bali, Indonesia. Species Diversity, 6: 323-345.

Vitzthum, H. G. (1931) Résultats scientifiques du voyage auz Indes Orientales Néerlandaises. Acarinen. Mémoires du Musée Royal d'Histoire Naturelle de Belgique, Hors Série 3: 1-55.

Walter, D. E. and G. W. Krantz (1986) A review of glaber-group (s. str.) species of the genus Macrocheles (Acari: Macrochelidae), and a discussion of species complexes. Acarologia, 27: 277-294. 


\section{摘要}

インドネシア・スラウェシ島の食糞性甲虫類に見られるハエダニ類（ダニ目：トゲダニ亜目： ハエダニ科)

Sri HARTINI・Dhian DWIBADRA（インドネシア科学院・生物学研究所）・高久元 (北海道教 育大・札幌)

インドネシア・スラウェシ島に执いて採集された食糞性甲虫の体表から，八エダニ科 2 属 17 種が確認された. 1 種 (Macrocheles kraepelini) を除く 16 種は, スラウェシ島から初めて 記録された種であった. それらのらち，6 種 (M. convexus, M. donggalensis, M. persimilis, M. pilosellus, M. simulans, M. variodecoratus）を新種として記載した. また，これまでインドネシ アから記録されている 4 属 55 種に関して，属および種までの検索表を付記した． 